\title{
Effect of farmyard manure and rhizobium inoculation on growth of chickpea (Cicer arietinum L.) variety "karak-03"
}

\author{
Nangial Khan ${ }^{1 *}$, Farooq Nawaz ${ }^{1}$, Abdullah Khan ${ }^{2}$, Naveed Ul Haq ${ }^{3}$, Saif \\ Ullah $^{1}$, Anis Ur Rehman Khalil ${ }^{4}$, Sohail ${ }^{4}$, Adeel Liaqat ${ }^{1}$, Murad Ali $^{2}$, \\ Junaid Ali Shah ${ }^{4}$, Israr Ali ${ }^{5}$ and Mehran Ali ${ }^{1}$ \\ 1. Department of Agronomy, The University of Agriculture Peshawar-Pakistan \\ 2. Department of Horticulture, The University of Agriculture Peshawar-Pakistan \\ 3. Department of Food Science and Technology, The University of Agriculture Peshawar-Pakistan \\ 4. Department of Water management, The University of Agriculture Peshawar-Pakistan \\ 5. Department of Plant Breeding and Genetics, The University of Haripur-Pakistan. \\ *Corresponding author's email: nangialkhan@ hotmail.com \\ Citation \\ Nangial Khan, Farooq Nawaz, Abdullah Khan, Naveed Ul Haq, Saif Ullah, Anis Ur Rehman Khalil, Sohail, Adeel \\ Liaqat, Murad Ali, Junaid Ali Shah, Israr Ali and Mehran. Effect of farmyard manure and rhizobium inoculation on \\ growth of chickpea (Cicer arietinum L.) variety "karak-03". Pure and Applied Biology. Vol. 6, Issue 1, pp378-384. \\ http://dx.doi.org/10.19045/bspab.2017.60037
}

Received: $27 / 10 / 2016$

Revised: 01/03/2017

Accepted: 04/03/2017

Online First: 06/03/2017

\section{Abstract}

The experiment was performed at the Agronomy Farm in The University of Agriculture Peshawar, Pakistan during winter 2015 using simple randomized completely block design (RCBD) with three replications. The experiment contained a total of 32 treatment units. FYM application at four levels $\left(0,5,10\right.$, and 15 ton ha $\left.{ }^{-1}\right)$ with variety (Inoculated and non-inoculated) were included in experiment. FYM application@15 ton ha ${ }^{-1}$ resulted in a significant growth than5 ton $\mathrm{ha}^{-1}, 10$ ton ha ${ }^{-1}$ and the control. Similarly inoculated seeds produced better crop growth as compared to non-inoculated seed. The parameters such as plant height and nodule per plant were significantly affected by both the FYM and inoculation, while days required for emerging $50 \%$ plants and emergence per $\mathrm{m}^{2}$ were also significantly affected but only by FYM. Higher plant height (74.33) and nodule per plant (68.24) was counted in plots treated with FYM @ 15 ton $\mathrm{ha}^{-1}$ as compared to other levels. Similarly Higher plant height (73.54) and nodule per plant (69.50) was counted in plots with inoculated seeds. Hence application of FYM @ 15t ha-1 and inoculation with Rhizobium strains are the recommended practices for better growth and crop stand of chickpea.

Keywords: Chickpea; Rhizobium inoculation; Farm yard manure

\section{Introduction}

Chickpea (Cicer arietinum L.) is a crucial winter pulse crop. It lies third in the world in manner of grain legume grown, after soybean and beans. Archaeological studies manifest chickpea to be domesticated in the sub-continent and Middle East. Chickpea is morphologically categorized into two major 
classes, desi and kabuli. The previous types possess short stature plants that bear purplish flowers and tiny leaflets whereas the angular seeds vary in colour ranging from brown, black and yellow to green. The plants also carry anthocyanin pigmentations. However the Kabuli types have medium heighted plants that hold white flowers, large leaflets, while seeds are round, large and creamy in appearance. The kabuli type plants are deficient in anthocyanin pigmentations $[1,2]$.

Chickpea is placed in the world's significant leguminous crops, which is used as a source of food for human beings and feed for livestock. Its seeds are very nutritive as they are rich in proteins, containing 25.3-28.9\% when the hulls are removed. Seeds of chickpea can be taken as fried, fresh green, boiled, roasted or as snack food. When crushed, the seeds transform into flour that can be utilized in preparing dhal, soup as well as bread. Among these, dhal contains the inner material of chickpea seeds without seed coat that are dried and later on prepared into a thickened soup [3].

Pakistan is the second largest producer of chickpea with chickpea production of about 842 thousand tonnes annually, being after India (5970 thousand tonnes) in the world [4]. Out of the total cropped area of Pakistan, only about $7 \%$ area is used for the cultivation of pulses in which the share of chickpea cultivation is $73 \%$. However, chickpea production in Pakistan is around 496 thousand tones which is obtained from an area of 1055 thousand hectares with $471 \mathrm{~kg} \mathrm{ha}{ }^{-1}$ as an average yield [4]. In Khyber Pakhtunkhwa chickpea is cultivated using an area of 37.6 thousand hectares and produces over 21.0 thousand tons with $532 \mathrm{~kg} \mathrm{ha}^{-1}$ as an average yield [5]. However among these, about $75 \%$ is obtained from a rainfed area and is mostly cultivated in southern districts of the province including
Bannu, Karak, Lakki Marwat, Tank and Dera Ismail Khan.

Plants require amino acids for the production of proteins they need while nitrogen is an important element in the formation of amino acids and for plant metabolism. Plants cannot utilize atmospheric nitrogen rather they consume it in the form of either ammonium $\left(\mathrm{NH}_{4}{ }^{+}\right)$or nitrate $\left(\mathrm{NO}_{3}{ }^{-}\right)$. Chickpea plants have the capabilities to sustain the productivity of cropping system because of its ability to fix the atmospheric nitrogen. They possess root nodules where nitrogen fixing bacteria, Rhizobium exists having the task of renovating the atmospheric nitrogen into the form accessible by plants and this phenomenon is termed as biological nitrogen fixation (BNF). Through the biological nitrogen fixation, a substantial amount of nitrogen is produced and deposited in the surrounding soil, which is used by the plants [6]. Efficiency of producing maximum nitrogen by the plant is greatly concerned to the cultivar, number of nodules as well as the competent strain of Rhizobia residing in their root nodules.

Chickpea has a potential yield much greater than its average yield. The lower average yield may be due to the lack of effective Rhizobial strain, unavailability of fine quality seeds and also by damages due to blight and attack of pod borers. Moreover Pakistan has a soil deficient in nitrogen, which greatly affects plant metabolism and protein synthesis resulting in lower yields by the crop. However, the soils which are deficient in effective and compatible Rhizobia can be managed by artificially inoculating the chickpea seeds and this is a very helpful technique used for amending roots nodulation and also the crop yield [7]. Extending the function of biofertilizers like Rhizobium can effectively reduce the usage of synthetic chemical fertilizers which conversely reduces adverse effects on the 
environment. Being a legume crop, chickpea fulfils a significant amount (4-85\%) of its nitrogen requirements through the process of symbiotic nitrogen fixation when it is grown in association with native and effective Rhizobium strains [8-10]. Chickpea in association with Rhizobium can produces about $176 \mathrm{~kg} \mathrm{~N} \mathrm{ha}{ }^{-1}$ annually, which is strictly concerned with the bacterial strain, the cultivar and also the environmental factors involved [11].

\section{Materials and methods}

The present studies were performed at New Developmental Farm, The University of Agriculture, Peshawar during the chickpea cropping season of the year 2014-15. The chickpea variety (karak-03) was evaluated under inoculated and non-inoculated conditions subjected to four different farmyard manure levels. The experiment was plotted in RCB Design with four replications. Each Variety was planted in six rows of $3 \mathrm{~m}$ length with R-R distance of 30 $\mathrm{cm}$ and $\mathrm{P}-\mathrm{P} 10 \mathrm{~cm}$ and plot-plot $60 \mathrm{~cm}$ separation. All recommended practices and inputs will be uniformly applied to each experimental unit.

Factor "A"

FYM $\left(0,5,10,15 \mathrm{tha}^{-1}\right)$

Factor "B"

Rhizobium inoculated seed (i2) and noninoculated seed (i1).

Data will be recorded keeping in mind the following parameters;

1. Days required to $50 \%$ emergence

2. Emergence per meter ${ }^{2}$

3. Days required to $50 \%$ flowering

4. Plant height

5. Days required to maturity.

\section{Days required to $50 \%$ emergence}

The number of days required to emerge $50 \%$ plants was calculated by counting the number of days past from the date when seeds were sown to the time when $50 \%$ of these seeds emerged and afterwards an average was calculated.

\section{Emergence per meter ${ }^{2}$}

Data on the emergence per meter ${ }^{2}$ was calculated by counting the number of seedling in one square meter row selecting three random positions in each plot and this was converted into an average number of plants emerged $\mathrm{m}^{-2}$ according to the following formula.

Emergence $\mathrm{m}^{-2}=$ no of seedling counted $\times 100$ Row-row distance $\mathrm{x}$ row length $\mathrm{x}$ no. of rows

\section{Days required to $50 \%$ flowering}

The number of days required to flower $50 \%$ of the plants was calculated counting the number of days past from the date of sowing the seeds to the time when $50 \%$ of these plants appeared with first flower and then subsequently an average was also calculated. Plant height (cm)

Height of plants was recorded when plants turned brown and ceased to grow, by measuring from ground level to the tip in randomly selected plants using a meter rod. The heights were measured in centimetres scale.

\section{Days required to maturity}

The number of days required to maturity was recorded when $90 \%$ of plants turned brown and were ready for harvest. It was achieved by counting the total number of days the plant required from the date of planting till its maturity and further average was also calculated.

\section{Nodules per plant}

Data on the number of nodules per plant were obtained at the time of flowering and this was enabled by counting the number of nodules in each of the randomly selected ten plants within each sub plot. The portion where sampling was desired was thoroughly irrigated before procedure.

\section{Statistical analysis}

Data was analyzed by using statistical package 'Statistix 8.1'.

\section{Results}

Days required to $50 \%$ emergence

Data for the number of days required to emerge $50 \%$ of the plants are presented in 
Table 1. Statistical analysis indicated that the response of FYM were significant. Mean Table clear that FYM @ $15 \mathrm{t} \mathrm{ha}^{-1}$ take least number of days (17.38) to emergence followed by FYM @ 10 t ha ${ }^{-1}(21.13)$. However control plot take more number of days (23.25) to emergence. This might be due to effect of FYM on soil properties because it enhances soil structure, soil life, water holding capacity, and aeration which is responsible for better emergence. However, the response of inoculation was non-significant.

Table 1. Days required for emerging $50 \%$ of chickpea plants which are affected by farm yard manure and by inoculation

\begin{tabular}{|l|c|c|c|}
\hline FYM & i1 & i2 & Mean \\
\hline F1 & 23.25 & 23.25 & $23.25 \mathrm{a}$ \\
\hline F2 & 21.25 & 24.00 & $22.63 \mathrm{ab}$ \\
\hline F3 & 21.25 & 21.00 & $21.13 \mathrm{~b}$ \\
\hline F4 & 18.75 & 16.00 & $17.38 \mathrm{c}$ \\
\hline & $21.13 \mathrm{a}$ & $21.06 \mathrm{~b}$ & \\
\hline
\end{tabular}

Means followed by different letters in the same category are significantly different using LSD test $(\mathrm{P} \leq 0.05)$

$\mathrm{LSD}$ value for $\mathrm{FYM}=1.94$

LSD value for Inoculation $=1.37$

LSD value for interaction $(\mathrm{FYM} \mathrm{x} \mathrm{In)}=2.74$

\section{Emergence $\mathbf{m}^{2}$}

Statistically analysis of the data (Table 2) revealed that FYM were significantly affected. From the mean Table it is concluded that FYM @ $15 \mathrm{t} \mathrm{ha}^{-1}$ gives higher emergence $\mathrm{m}^{2}$ (36.42) followed by FYM@10 tha' ha $\left.^{-1} 33.19\right)$. However, FYM @ $5 \mathrm{t} \mathrm{ha}^{-1}$ resulted in least emergence $\mathrm{m}^{2}$
(31.90). This might be due to effect of FYM on soil internal environment including soil porosity, soil structure, aeration soil microbial activities which are responsible for better emergence. Moreover the response of inoculation was non-significant. However inoculated variety give higher emergence $\mathrm{m}^{2}$ (34.30) then non-inoculated.

Table 2. Emergence $\left(\mathrm{m}^{-2}\right)$ of chick pea as affected by farm yard manure and inoculation

\begin{tabular}{|l|c|c|c|}
\hline FYM & i1 & i2 & Mean \\
\hline F1 & 31.98 & 33.46 & $32.72 \mathrm{~b}$ \\
\hline F2 & 31.22 & 32.59 & $31.90 \mathrm{~b}$ \\
\hline F3 & 33.55 & 32.82 & $33.19 \mathrm{~b}$ \\
\hline F4 & 34.49 & 38.35 & $36.42 \mathrm{a}$ \\
\hline & $32.81 \mathrm{a}$ & $34.30 \mathrm{a}$ & \\
\hline
\end{tabular}

Means followed by different letters in the same category are significantly different using LSD test $(\mathrm{P} \leq 0.05)$

$\mathrm{LSD}$ value for $\mathrm{FYM}=2.18$

LSD value for Inoculation $=1.54$

LSD value for interaction (FYM x In) $=3.08$

Days required to $50 \%$ flowering

Data for the number of days spent to $50 \%$ flowering are represented in Table 3 . Statistical analysis revealed that the response of FYM were non-significant. From the mean Table it is concluded that
FYM applied @ $10 \mathrm{t} \mathrm{ha}^{-1}$ take least number of days (128.25) to $50 \%$ flowering fallowed by control plot (129), however, FYM applied@5 t ha ${ }^{-1}$ take maximum days (134.50) to $50 \%$ flowering. However, the response of inoculation was non-significant. 
Table 3. Days required to $50 \%$ flowering of chick pea as affected by farm yard manure and inoculation

\begin{tabular}{|l|l|l|l|}
\hline FYM & i1 & i2 & Mean \\
\hline F1 & 127.75 & 130.25 & $129.00 \mathrm{ab}$ \\
\hline F2 & 134.25 & 134.75 & $134.50 \mathrm{a}$ \\
\hline F3 & 127.25 & 129.25 & $128.25 \mathrm{~b}$ \\
\hline F4 & 131.00 & 129.75 & $130.38 \mathrm{ab}$ \\
\hline & $130.06 \mathrm{a}$ & $131.00 \mathrm{a}$ & \\
\hline
\end{tabular}

Means followed by different letters in the same category are significantly different using LSD test $(\mathrm{P} \leq 0.05)$

LSD value for $\mathrm{FYM}=5.77$

LSD value for Inoculation $=4.08$

LSD value for interaction $(\mathrm{FYM} \times \mathrm{In})=8.16$

\section{Plant height}

Data regarding plant height are expressed in Table 4. From mean Table it is concluded that the response of FYM and inoculation were statistically significant. From mean Table it is shown that FYM applied @ 15t ha $^{-1}$ give higher plant height (74.33) which is statistically non-significant to FYM @ 10 and $5 \mathrm{t} \mathrm{ha}^{-1}$. Control plot give lower plant height (68.59).These results are in conformity with that of [12] who showed that maximum height of a plant was attained by plots receiving 15 tons FYM ha ${ }^{-1}$ while on the other hand a minimum height of plant was noted in plots that had obtained no FYM. Similarly inoculated variety perform better (73.54) than non-inoculated variety (70.51). These results are in line with [13] who represented inoculated plants to have more height than the non-inoculated plants.

Table 4. Plant height of chick pea as affected by farm yard manure and inoculation

\begin{tabular}{|l|l|l|l|}
\hline FYM & i1 & i2 & Mean \\
\hline F1 & 67.47 & 69.72 & $68.59 \mathrm{~b}$ \\
\hline F2 & 71.95 & 74.56 & $73.25 \mathrm{a}$ \\
\hline F3 & 70.27 & 73.62 & $71.94 \mathrm{ab}$ \\
\hline F4 & 72.38 & 76.27 & $74.33 \mathrm{a}$ \\
\hline & $70.51 \mathrm{~b}$ & $73.54 \mathrm{a}$ & \\
\hline
\end{tabular}

Means followed by different letters in the same category are significantly different using LSD test $(\mathrm{P} \leq 0.05)$

$\mathrm{LSD}$ value for $\mathrm{FYM}=3.75$

LSD value for Inoculation $=2.65$

LSD value for interaction $(\mathrm{FYM} \times \mathrm{In})=5.31$

\section{Days to maturity}

Data for the number of days required to mature the plants are shown in Table 5. Statistically, analysis depicted the response of FYM and inoculation was nonsignificant. From the mean Table it is concluded that FYM applied @ $5 \mathrm{t} \mathrm{ha}^{-1}$ take least number of days to maturity(176.13) followed by FYM applied @ $10 \mathrm{t} \mathrm{ha}^{-1}($ 176.75).However, the response of inoculated variety (179.63) was better than noninoculated variety (175.94). 
Table 5. Days to maturity of chick pea as affected by farm yard manure and inoculation

\begin{tabular}{|l|l|l|l|}
\hline FYM & i1 & i2 & Mean \\
\hline F1 & 180.75 & 174.75 & $177.75 \mathrm{a}$ \\
\hline F2 & 171.25 & 181.00 & $176.13 \mathrm{a}$ \\
\hline F3 & 175.50 & 178.00 & $176.75 \mathrm{a}$ \\
\hline F4 & 176.25 & 184.75 & $180.50 \mathrm{a}$ \\
\hline & $175.94 \mathrm{a}$ & $179.63 \mathrm{a}$ & \\
\hline
\end{tabular}

Means followed by different letters in the same category are significantly different using LSD test $(\mathrm{P} \leq 0.05)$

LSD value for $\mathrm{FYM}=6.83$

LSD value for Inoculation $=4.83$

LSD value for interaction $($ FYM x In $)=9.66$

\section{Nodule per plant}

Data regarding nodule per plant is expressed in Table 6. From mean Table it is concluded that the response of FYM and inoculation were statistically significant. From mean Table it is shown that FYM applied @ 15t $\mathrm{ha}^{-1}$ give more number of nodule per plant (68.68) which is statistically non-significant to FYM @ 5 and $10 \mathrm{t} \mathrm{ha}^{-1}$ and control plant have less number of nodule per plant (57.85).These results are in with conformity to that of [12] who concluded that maximum number of nodules per plant was recorded for the plot when treated with FYM @ 15t ha $^{-1}$ while minimum number of nodules was recorded for control plots. Similarly inoculated variety gives more number of nodule plant $^{-1}$ (69.50) than non-inoculated variety (57.71).These result are in line with the findings of other scientist who observed that the total number of nodules per plant were the highest in plant inoculated with Rhizobium [14], while all the interactions were found non-significant.

Table 6. The number of nodules per chick pea plant as affected by farm yard manure and inoculation

\begin{tabular}{|l|l|l|l|}
\hline FYM & i1 & i2 & Mean \\
\hline F1 & 51.81 & 63.88 & $57.85 \mathrm{~b}$ \\
\hline F2 & 53.24 & 75.63 & $64.44 \mathrm{ab}$ \\
\hline F3 & 61.97 & 65.80 & $63.88 \mathrm{ab}$ \\
\hline F4 & 63.80 & 72.68 & $68.24 \mathrm{a}$ \\
\hline & $57.71 \mathrm{~b}$ & $69.50 \mathrm{a}$ & \\
\hline
\end{tabular}

Means followed by different letters in the same category are significantly different using LSD test $(\mathrm{P} \leq 0.05)$

$\mathrm{LSD}$ value for $\mathrm{FYM}=6.97$

LSD value for Inoculation $=4.92$

LSD value for interaction $(\mathrm{FYM} \mathrm{x}$ In) $=9.85$

\section{Conclusions}

It was concluded from the research that:

1. Farm yard manure applied at the rate of $15 \mathrm{t} \mathrm{ha}^{-1}$ gave us better growth and yield as compared to other levels.

2. Inoculated seed gave us better growth and yield as compared to non-inoculated seed.

\section{Recommendation}

Farm yard manure application at $15 \mathrm{tha}^{-1}$ and inoculation with Rhizobium strains is recommended for better growth and yield of chick pea.

\section{Authors' contributions}

Conceived and designed the experiments: $\mathrm{N}$ Khan \& F Nawaz, Performed the experiments: F Nawaz, S Ullah, M Ali \& A Liaqat, Analyzed the data: JA Shah, A Khan 
\& AU Rehman, Contributed reagents/ materials/ analysis tools: NU Haq, I Ali, M Ali \& Sohail, Wrote the paper: N Khan.

\section{References}

1. Hulse JH (1991). Nature, composition and utilization of grain legumes. In: Uses of tropical legumes. Pages 11-27 in proceedings of a Consultant's Meeting, 27-30 March 1989, ICRISAT Center. ICRISAT, Patancheru, A.P. 502-324, India.

2. FAOSTAT (2010-11). Food and Agriculture Organization of the United Nations, FAO Statistical Databases. Availible at http//.faostat.fao.org.

3. FBS (2010-11). Federal Bureau of Statistics.Ministry of Economic Affairs and Statistics Islamabad, Pak.

4. Khattak SG, Khan DF, Shah SH, Madani MS \& Khan T (2006). Role of Rhizobial inoculation in the production of Chickpea crop. Soil \& Environ 25(2): 143-145.

5. Saini VK, Bhandari SC \& Tarafdar JC (2004). Comparison of crop yield, soil microbial $\mathrm{C}, \mathrm{N}$ and $\mathrm{P}, \mathrm{N}$-fixation, nodulation and mycorrhizal infection in inoculated and non-inoculated sorghum and chickpea crops. Field Crops Research 89: 39-47.

6. Rudresh DL, Shivaprakash MK \& Prasad RD (2005). Effect of combined application of Rhizobium, phosphate solubilizing bacterium and Trichoderma spp. on growth, nutrient uptake and yield of chickpea (Cicer aritenium L.). Applied Soil Ecology 28: 139-146.

7. Togay N, Togay Y, Cimrin KM \& Turan M (2008). Effect of Rhizobium inoculation, sulfur and phosphorus application on yield, yield components and nutrient uptake in chick pea (Cicer aretinum L.). African Journal of Biotechnology 7(6): 776-782.

8. Ogutcu H, Algur OF, Elkoca E \& Kantar (2008). The determination of symbiotic effectiveness of Rhizobium strains isolated from wild chickpea collected from high altitudes in Erzurum. Turkish Journal of Agriculture and Forestry 32: 241-248.

9. Bashir A, Shah Z, Naeem M, Bakht J \& khan ZH (2008). Effect of phosphorus and farm yard manure on agronomic traits of chickpea (Cicer arietinum L.). Sarhad J Agric 24(4).

10. Caliskan S, Erdogan C, Arslan M \& Caliskan ME (2013). Comparison of organic and traditional production systems in chickpea (Cicer arietinum L.) Turkish J of Field Crops 18(1): 3439.

11. El-Hadi EA \& El-Sheikh EAE (1999). Effect of Rhizobium inoculation and nitrogen fertilization on yield and protein contents of six chickpea (Cicer arietinum L.) cultivars in marginal soils under irrigation. Nutrient Cycling in Agro-ecosystems 54: 63-75. 